\title{
Seasonal variations in concentrations and fluxes of dissolved organic and inorganic materials in a tropical, tidally-dominated, mangrove waterway*
}

\author{
Kevin G. Boto, John T. Wellington \\ Australian Institute of Marine Science, P.M.B. No. 3, Townsville MC, Queensland, 4810, Australia
}

\begin{abstract}
Variations in concentrations, and extent of outwelling, or import, of dissolved inorganic and organic materials were examined over 16 tidal cycles during a 20 mo period, in a tropical mangrove system at Hinchinbrook Island, northern Australia. Previous studies of this system have shown that ca $35 \%$ of the forest net primary production (as carbon) is exported to nearby coastal waters through tidal export of particulate organic matter, primarily mangrove plant litter. Concentrations of dissolved organic carbon (DOC), nitrogen (DON), and phosphorus (DOP), along with inorganic nitrogen and phosphorus species (ammonium, nitrate, nitrite and soluble reactive phosphate) were consistently much lower, by up to an order of magnitude, than those reported for many temperate salt marsh or estuarine mangrove waters. Significant $(p<0.05)$ variations in mean concentrations of all dissolved materials with time of year were found, although no consistent seasonal periodicity was apparent. Nitrate + nitrite was the only component which showed a strong relationship with simple variables, notably solar radiation and water temperature, as demonstrated by multiple regression analysis $\left(R^{2}=0.79\right)$. The dissolved organic materials did not appear to be linked with the photosynthetic activity of phytoplankton, benthic algae or the mangroves as there was no day-night variation in their concentrations. This contrasted with the inorganic nutrients which showed small but statistically significant differences between daytime and nighttime concentrations. A consistently high atomic $\mathrm{C}: \mathrm{N}$ or $\mathrm{C}: \mathrm{P}$ ratio for the dissolved organics (18 to $35: 1$ and 250 to $700: 1$ respectively) suggests that this material is mostly refractory and in an advanced diagenetic stage, for example, fulvic acids. Statistically significant net fluxes over individual tidal cycles were obtained in most cases for DOC, nitrate + nitrite, and soluble reactive phosphate. The other entities, particularly ammonium, showed very large and apparently random variations over space and time throughout a tidal cycle thus preventing accurate estimates of their fluxes. In all cases, however, there was no apparent seasonal variation in the direction or magnitude of net fluxes, and, integrating over a year, all components showed very small and negligible net transport to or from the system, except for total dissolved P which showed a net annual import amounting to $24 \%$ of net forest primary production requirements. The apparently finely balanced situation for dissolved material transport in this tidally dominated tropical system with virtually no terrestrial inputs is contrasted with the more usual 'outwelling' of dissolved materials from temperate salt marsh systems.
\end{abstract}

\section{INTRODUCTION}

The chemical and biological links between mangroves and near-shore waters are poorly understood. As a major first step in defining such links, it is important to determine the rates and direction of material fluxes from mangroves to adjacent coastal waters. Do mangroves export significant quantities of carbon, nitrogen and phosphorus and hence 'subsidize' the food chains in the coastal waters and subtidal benthos or,

\footnotetext{
- A.I.M.S. Contribution No. 446
}

alternatively, do mangroves function as a sink for carbon and nutrients? Further, are the flux rates and directions subject to seasonal variations?

Studies of particulate and dissolved carbon/nutrients transport from salt marshes, carried out since the midseventies (e.g. Settlemeyer \& Gardner 1977, Valiela et al. 1978, Haines 1979, Chrzanowski et al. 1983, Imberger et al. 1983, Chalmers et al. 1985) have given equivocal and sometimes conflicting answers. Although it appears that salt marshes in general are net exporters of carbon and some forms of inorganic nutrients, the amounts involved are much less than 
originally hypothesized when the concept was first introduced by Teal (1962). The diversity of the results obtained lend support to the concept, advanced by Odum et al. (1979), that the extent of outwelling from a particular marsh is related to specific factors such as geographic location, morphology and hydrology rather than to any universal feature of marshes. To further complicate the issue, many of the saltmarsh studies have involved methodologies which have been questioned by other workers in the field. For example, Imberger et al. (1983) have been critical of the 'Eulerian' approach whereby water flows and material content are measured at a fixed point and budgets subsequently calculated by summation of the small mass flow increments derived from these measurements over a tidal cycle.

Even less information is available for mangrove systems. There is no valid reason to assume that results, models or hypotheses derived from the temperate marsh studies can be extrapolated to the tropical tidal forests. The small amount of evidence to date suggests that direct tidal export of mangrove litter may be considerable (Odum et al. 1982 and references therein).

Boto \& Bunt $(1981 \mathrm{a}, 1982)$ estimated that up to $46 \%$ of the mangrove primary production in a northern Australian forest was subject to export as macro- (e.g. leaves and other intact plant parts) and micro-particulate matter. These estimates subsequently have been revised downwards by Robertson (1986) who found that the original study underestimated the high degree of leaf litter consumption by sesarmid crabs within the forest. Nevertheless, the revised estimate of $1.5 \mathrm{~g}$ dry wt $\mathrm{m}^{-2} \mathrm{~d}^{-1}$ (22\% less than the previous estimate) still represents a substantial direct export of mainly intact plant detritus. This can be directly compared with the situation for the Duplin River-salt marsh system studied by Chalmers et al. (1985) where it is estimated that export of Spartina wrack is negligible in terms of overall carbon mass balance.

Woodroffe (1985a, b) also found that direct tidal flushing of mangrove litter was significant in both a tropical (Darwin Harbour, northern Australia) and a sub-tropical (Tuff Crater, New Zealand) mangrove forest, although he points out that the local forest topography and tidal range will be important factors in determining the extent of such flushing. Twilley's (1985) studies of basin forests in Florida, a system in which negligible litter flushing occurs, serves to emphasize this point albeit such forests represent an extreme topographic situation.

Few estimates of dissolved organic matter concentrations in, or fluxes from, mangrove forests are available. Balasubramanian \& Venugopalan (1984) examined seasonal variations in dissolved organic carbon, nitrogen and phosphorus in a tropical mangrove system in southern India. These authors found a very pronounced seasonal variation in DOC concentrations with peaks up to $4.9 \mathrm{mg} \mathrm{Cl}^{-1}$ associated with periods of high phytoplankton populations. According to Twilley (1985), for infrequently flushed basin forests, dissolved organic carbon (DOC) accounted for up to $75 \%$ of the total carbon export ( $64 \mathrm{~g} \mathrm{C} \mathrm{m}^{-2} \mathrm{yr}^{-1}$ ). Odum et al. (1982) suggested that DOC export from other types of mangrove forest may also be considerable but offer no evidence to support this supposition. Similarly, there is a lack of information on dissolved organic and inorganic nutrient fluxes (Boto 1982). Odum et al. (1982) further suggested that mangroves act as a sink for various elements including nitrogen and phosphorus.

This concept has little direct evidence to support it although Nixon et al. (1984) have reported some preliminary data from a study of estuarine-seawater mixing in Malaysia which suggested that both a mangrove-lined estuary and an estuary devoid of mangroves functioned as sinks for some particulate and dissolved nutrients.

This paper describes a 20 mo study of dissolved organic and inorganic matter in a tropical mangrove tidal channel in northern Australia, where previous studies have shown a significant amount of plant litter export as described above. The seasonal variations in concentrations and fluxes of DOC, dissolved organic nitrogen and phosphorus (DON, DOP), ammonium, nitrate, nitrite and phosphate were estimated in order to obtain detaileci information on the role and importance of these entities in the overall energy and nutrient budgets of a tropical mangrove system. The almost complete lack of terrestrial runoff or freshwater input into the system simplifies the interpretation of the data and provides a valuable baseline for comparison with future studies of systems affected by other than purely tidal inputs. In addition, the information obtained enables more detailed comparisons between the tropical mangroves and their temperate salt marsh counterparts.

\section{METHODS}

The study was conducted in Coral Creek, Hinchinbrook Island in northeastern Australia, the same mangrove forest-tidal channel system used for the previous study of particulate matter fluxes (Boto \& Bunt 1981a). A complete description of this study site is given in the earlier reference. Briefly, the mangrove forest and its associated waterway are almost completely tidally dominated with minimal freshwater input occurring only during heavy monsoonal rain periods. Even at those times, the channel water salinities rarely are lower than $33 \%$ (Wolanski \& Gardiner 1981). The channel basin area, comprising ca $5 \mathrm{~km}^{2}$, is completely 
occupied by mangrove forest. Coral Creek is ca $6 \mathrm{~km}$ long and at the mouth is $160 \mathrm{~m}$ wide and $7 \mathrm{~m}$ deep at low spring tides. The associated mangrove forest is comprised of (in decreasing order of dominance) Rhizophora stylosa, R. apiculata, Ceriops tagal, Bruguiera gymnorrhiza and $R$. lamarckii.

The Coral Creek basin area has been surveyed in detail by the Australian Survey Office (Federal Government Department of Administrative Services). The survey information has also been summarized in previous publications by Boto \& Bunt (1981a) and Wolanski et al. (1980). The latter authors have constructed a hydrodynamic model of the Coral Creek system which accurately predicts water flow in the tidal channels and surrounding forest at any stage of a tidal cycle.

Sampling was conducted over 16 tidal cycles at ca 1 to 2 mo intervals during December 1982 to July 1984. Water samples were drawn up into pre-washed glass bottles, using a small battery-powered pump, through teflon tubing held in position at the appropriate depth with a long fiberglass rod. The first $50 \mathrm{ml}$ of the sample was discarded to minimize contamination from water remaining in the teflon tubing. The sampling position was near the mouth of the channel. At each half-hour time period during a complete $12 \mathrm{~h}$ tidal cycle, water was sampled at various depths or locations across the channel (one separate sample at each point) in order to examine the spatial variability in the concentrations of the various chemical entities. For example, simultaneous samples were taken at the water surface and $0.5 \mathrm{~m}$ from the bottom of the deep channel during 2 separate tidal cycles. On all other runs samples, at mid depth, were taken near the edge and in the middle of the channel.

Samples were immediately filtered $(0.4 \mu \mathrm{m}$ pore size Nuclepore filters - prewashed with $50 \mathrm{ml}$ of seawater) into teflon bottles and frozen on dry ice. They were kept frozen until laboratory analyses, which were usually completed within $1 \mathrm{wk}$, and always within $2 \mathrm{wk}$, after collection.

DOC analyses were carried out using the thin-film UV oxidation method described by Mueller \& Bandaranayake (1983). This method is very precise $195 \%$ confidence limits of $\pm 0.03 \mathrm{mg} \mathrm{Cl}{ }^{-1}$ in the range 0.2 to $2.0 \mathrm{mg} \mathrm{Cl}^{-1}$ ), although the efficiency of oxidation of 'real' samples is unknown. Mueller \& Bandaranayake (1983) carried out exhaustive testing of the oxidation efficiency for a wide range of organic compounds and found that the method gave better than $90 \%$ recovery for all but some nitrogen-containing species such as guanidine at concentrations of $5 \mathrm{mg} \mathrm{Cl}^{-1}$. At concentrations less than $3 \mathrm{mg} \mathrm{Cl} \mathrm{Cl}^{-1}$, virtually all compounds were oxidized at $100 \%$ efficiency.

We have therefore assumed that the method gave completely recovery for the DOC in Coral Creek waters where concentrations rarely exceeded $2 \mathrm{mg} \mathrm{l}^{-1}$.
DON and DOP analyses were carried out on a separate fraction of the same sample. Following $12 \mathrm{~h}$ digestion in a La Jolla UV photodigestion apparatus (Strickland \& Parsons 1972), samples were analysed for nitrate + nitrite (see below). The original nitrate + nitrite concentrations in the samples analysed for inorganic nutrients (these levels commonly being at least an order of magnitude lower) were subtracted to derive the concentrations of organic-N. DOP concentrations were determined in a similar manner from analysis of inorganic phosphate concentrations before and after prolonged UV digestion.

Analyses of inorganic nutrients were carried out on separate water samples taken at the same sampling location and time. The concentrations of ammonium, nitrate, nitrite and phosphate were determined using the autoanalyser techniques described by Ryle et al. (1981).

The July 1984 sampling was carried out over 2 consecutive tidal cycles to determine whether any significant diurnal variation in the concentrations of any of the dissolved entities could be detected. All other sampling was carried out during daytime only.

To illustrate the seasonal variations, means and standard deviations were determined from the total number of samples taken for each entity over a full tidal cycle $(30<n<50)$.

Water volumes within the channel-basin system at any given time during a tidal cycle were determined using the hydrodynamic model developed by Wolanski et al. (1980). The model utilizes tide heights measured at the channel mouth during each cycle. Tide heights were measured at each sampling period from a tide board installed by the Australian Survey Office. The tidal reference level used throughout is Australian High Datum (AHD). On this scale, some relevant tidal data for the Coral Creek system are: Mean sea level = $+0.15 \mathrm{~m}$, mean high water springs $=+1.2 \mathrm{~m}$, mean high water neaps $=+0.5 \mathrm{~m}$, mean low water neaps $=$ $-0.1 \mathrm{~m}$, mean low water springs $=-0.9 \mathrm{~m}$. Over an average tidal run, from +0.7 to $-0.7 \mathrm{~m}$, the water volume exchange is calculated to be $2.1 \times 10^{6} \mathrm{~m}^{3}$.

For calculation of net fluxes, within-cycle variations in the concentrations of dissolved components were taken into account along with a correction for the assymetry of water volume exchange between the ebb and flood half-cycles.

For each entity, linear regressions were constructed for the variation of concentration (Y) with volume of water (X) contained within the channel-basin. The separate regressions for the ebb and flood half-cycles were then compared for differences in slopes or adjusted means using standard analysis of covariance techniques (e.g. Sokal \& Rohlf 1981). If the regressions were significantly different $(p<0.05)$, the area 
between the 2 lines over the volume interval equivalent to an 'average' tidal cycle was calculated to derive the net mass inflow/outflow for that cycle. For some neap tide half-cycles this involved extrapolation of the regressions to the appropriate volume intervals. If the entity showed no significant regression with tidal volume then the ebb-flood tide comparisons were made using standard 1-way analysis of variance with the means for each half-cycle integrated over the appropriate volume interval. If the analysis of variance (or covariance) did not demonstrate a significant difference for the concentrations between the 2 halfcycles it was assumed that no net flux occurred over the tidal cycle. Annual total exchange estimates were obtained by calculation of mean tidal flux over the 16 cycles examined and multiplying by the number of tides per year.

This approach assumes a linear relation between concentration and volume, an assumption which was justified in this study by examination of the time-concentration data. Except for the case of ammonia (see 'Results'), there was no evidence for any pulses of water mass of different concentrations, but rather a generally smooth rate of change, if any change was apparent.

Detailed weather data for the study period were available from a Microdata weather station placed above the mangrove canopy near the channel edge and in very close proximity to the sampling location. This station measured the following at 30 min intervals: Rainfall, humidity, solar radiation, air temperature, mud temperature (probe placed $30 \mathrm{~cm}$ below the mud surface), wind speed and wind direction. These data were used to determine whether the seasonal variations in dissolved constituents could be related to simple climatic factors.

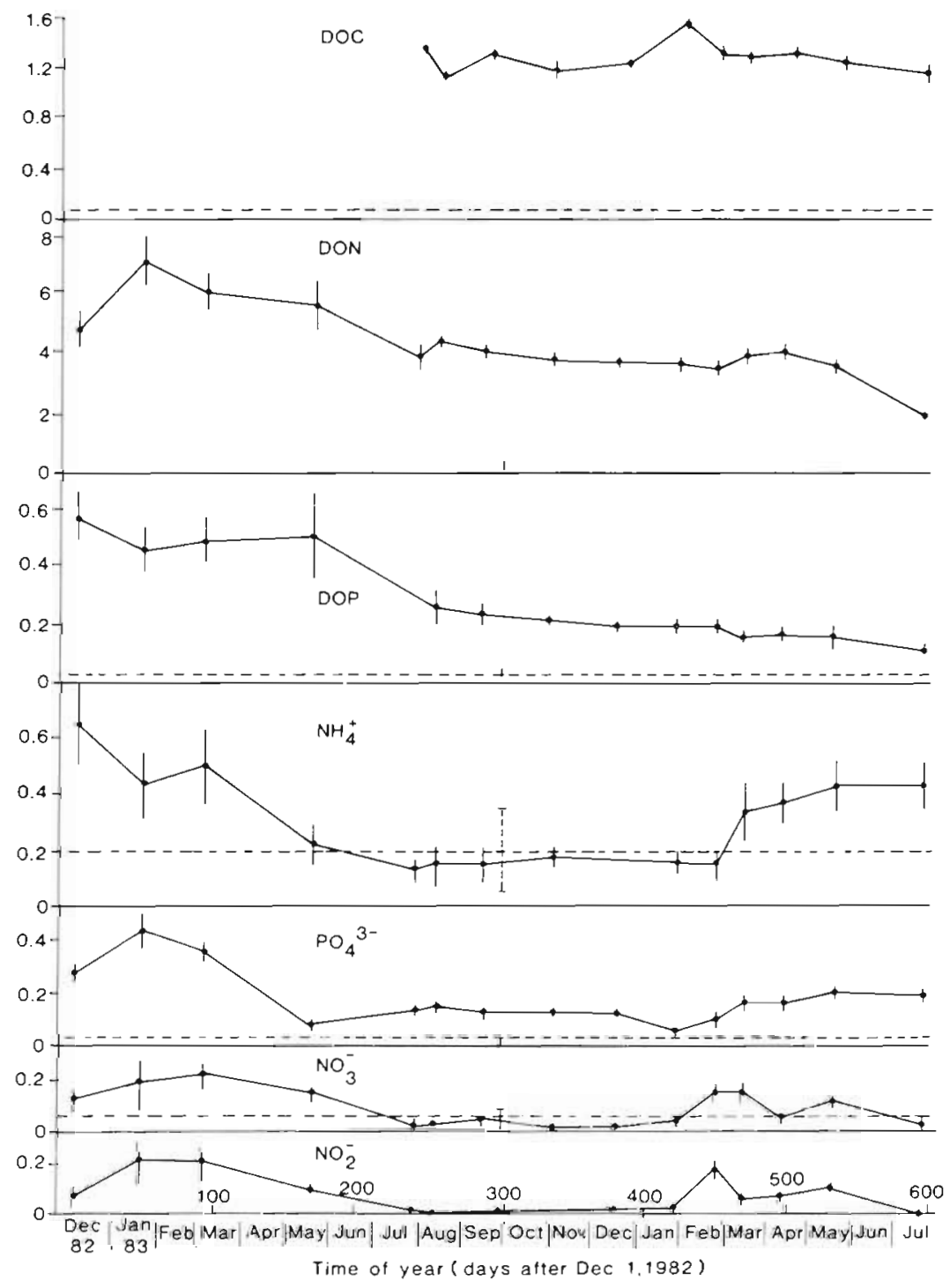

Fig. 1. Variation of mean concentrations of dissolved materials in Coral Creek over the 20 mo sampling period. Each mean was derived from 30 to 50 samples taken during each full tidal cycle on the sampling date shown. Vertical lines: $95 \%$ confidence intervals for each mean. Dashed horizontal lines: analytical detection limit and $95 \%$ confidence interval for the components according to Ryle et al. (1981) and Mueller \& Bandaranayake (1983). Units: $\mathrm{DOC}^{\mathrm{mg} \mathrm{Cl}}{ }^{-1}$, all others, umol $]^{-1}$ 
For these computations, it was assumed that the nutrient concentrations on any sampling day were in a quasi steady-state in response to the integrated effect of climatic conditions over a few days preceding and including the sampling date.

Hence, the climatic variables used in the final analyses were means derived from the daily means over an arbitrarily selected period of $7 \mathrm{~d}$, preceding and including the sampling date. The relationships between mean nutrient concentrations and climatic parameters were examined by calculation of standard correlation coefficients and stepwise multiple regression analysis (Sokal \& Rohlf 1981). Owing to the relatively low number of data points, the regression models were tested using the 'jackknife' procedure outlined by Geisser (1975). In this testing procedure, one datum at a time was deleted and a new regression developed. This was then used to predict the deleted datum. This procedure was repeated for all data points and a new $\mathrm{R}^{2}$ calculated for the set of predicted values.

\section{RESULTS}

Analyses of the results for the 2 cycles where the depth variation was examined (paired $t$-tests, comparing 'surface' and 'bottom' concentrations as pairs at each half-hour time period) showed no significant differences in concentration for any of the chemical entities with depth ( $p>0.3$ in all cases). Similarly, for all except DOC, there were no significant differences with position across the channel. For DOC, the concen- trations near the channel edge were on occasion statistically significantly greater $(p<0.05)$ than in the middle. However, the actual differences rarely exceeded $0.04 \mathrm{mg} \mathrm{Cl}^{-1}$, which was close to the expected analytical variation between any 2 samples. Hence, for the purposes of calculating mean concentrations and fluxes, the samples at each location/depth have been treated as simple replicates for each half-hour sampling period throughout each tidal cycle.

The mean concentrations of the dissolved materials and the timing and intensity of maxima, varied markedly during the 20 mo study (Figs. 1 and 2), although the concentrations were generally low, typical of tropical waters. Owing to instrument problems, no reliable DOC data were available for the first 4 sampling periods. Similarly there were no data for ammonium in December 1983 and DOP in July 1983.

In the 1982-83 summer period, the inorganic nutrient levels peaked during the period December to March and by July had decreased to levels near or below the limits of detection. In the following year, however, the peak was later - February to July - significantly reduced in magnitude (1-way ANOVA, $p<0.05$ ) and more prolonged, with ammonium and phosphate levels still significantly above detection limits in July. Concentrations of DOC, DON and DOP also varied significantly throughout the study period (1-way ANOVA, $p<0.05$ ) although no seasonal trends were apparent.

Correlations between the concentrations of the dissolved materials and the selected climatic parameters were generally low (Figs. 1 and 2, Table 1). From the weather data available, rainfall, water temperature

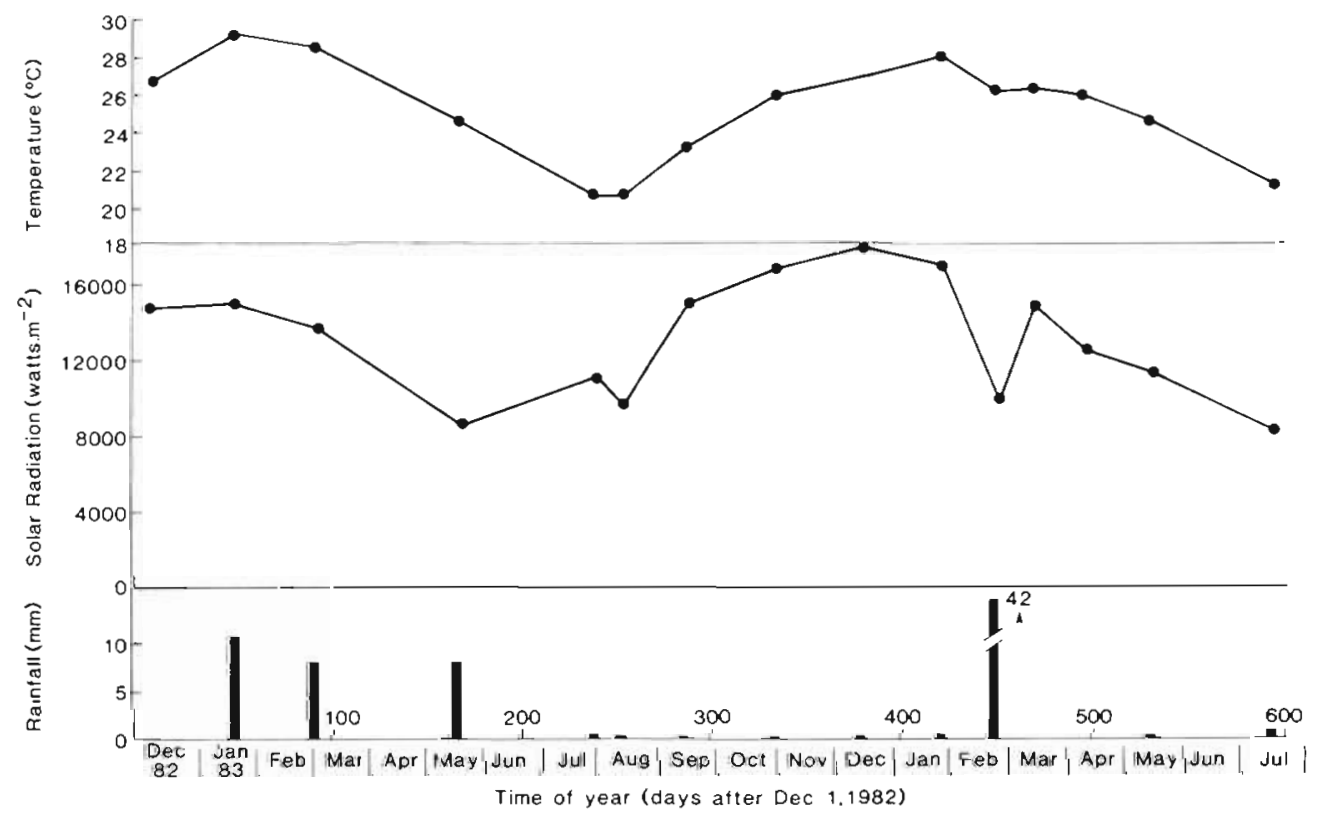

Fig. 2. Mean daily values of the climatic parameters (water temperature, total daily solar radiation energy, and daily rainfall totals) derived over a $7 \mathrm{~d}$ period preceeding and including the sampling dates 
Table 1. Correlations between dissolved entities and some simple climatic parameters (see text and Figs. 1 and 2 ). Only significant $(p<0.05$, d.f. $=13)$ correlations are shown for clarity

\begin{tabular}{lccccccc}
\hline & DON & DOP & $\mathrm{NH}_{4}$ & $\left(\mathrm{NO}_{3}+\mathrm{NO}_{2}\right)$ & $\mathrm{PO}_{4}$ & Temp & Rad \\
\hline $\mathrm{DOC}$ & & & & -0.661 & 0.531 \\
$\mathrm{DON}$ & - & 0.808 & & 0.617 & 0.594 & 0.528 \\
$\mathrm{DOP}$ & - & & & 0.753 & & \\
$\mathrm{NH}_{4}$ & & - & - & 0.607 & 0.615 & 0.585 \\
$\left(\mathrm{NO}_{3}+\mathrm{NO}_{2}\right)$ & & & - & - & 0.642 \\
$\mathrm{PO}_{4}$ & & & & & - \\
Temp & & & & & \\
\hline
\end{tabular}

(approximated in this case by mud temperature in the low intertidal zone), and solar radiation were considered to be the most likely parameters affecting the concentrations of the various dissolved entities. Although some are statistically significant, the low correlation coefficients nevertheless imply that the con- centrations of the various entities were only weakly, if at all, influenced by the macro-climatic variables examined in this study.

A possible exception to this general conclusion was the variation in the mean concentrations of nitrate + nitrite where slepwise multipie regression analysis
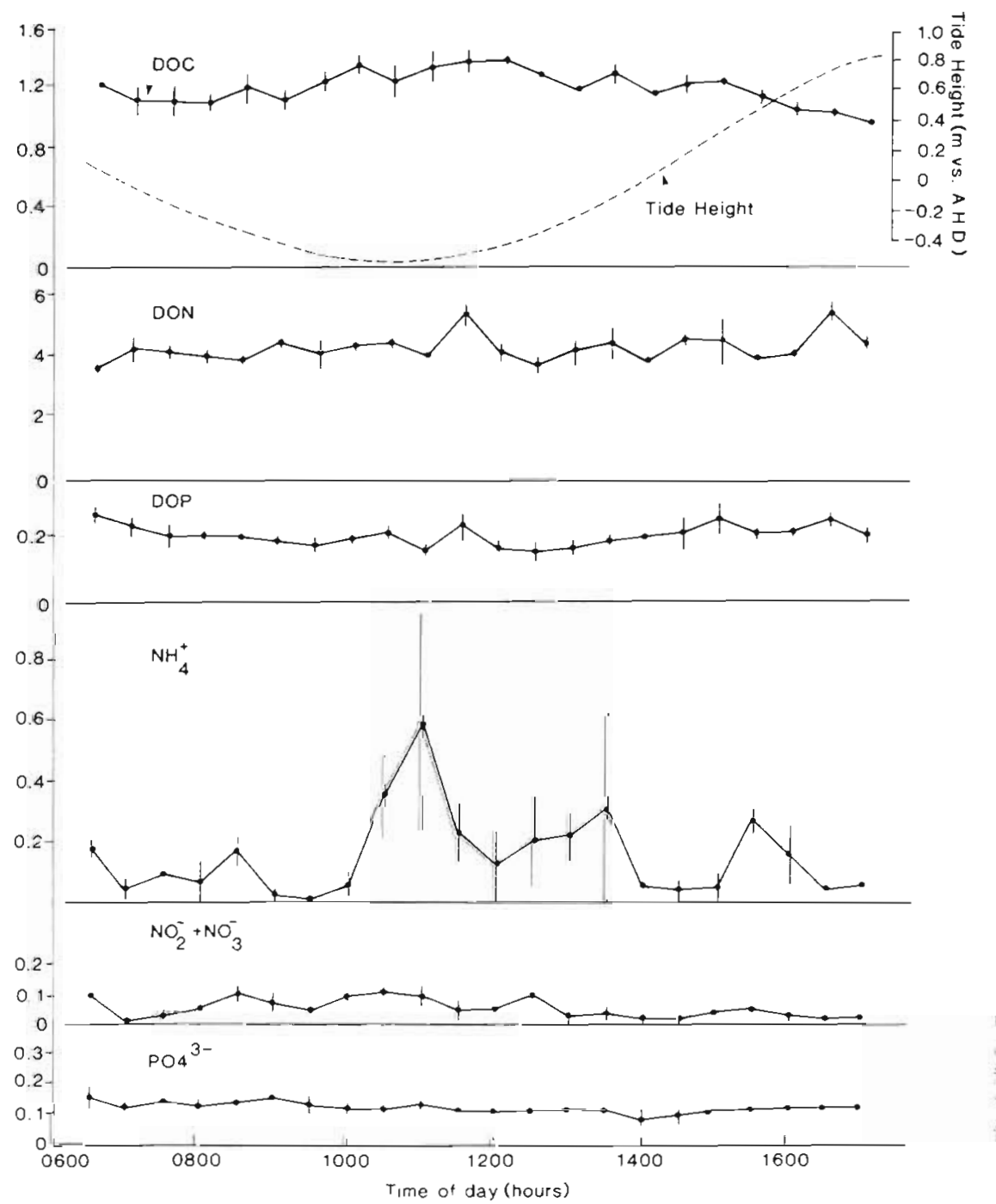

Fig. 3. Variation in the water level and mean concentrations of dissolved materials in Coral Creek with time of day during the full ndal cycle on Sep 14, 1983. Vertical lines: range of duplicate samples taken at each time interval. Units: Water level (m) vs Australian High Datum (AHD); dissolved materials as in Fig. 1 
Table 2. Estimates of net dissolved material exchanges calculated for average, symmetrical ebb and flood tidal runs on each sampling date (only month shown), derived from the regression and covariance analyses as described in the text. Negative values denote net export. Estimates enclosed in parentheses were not statistically significant at $p<0.05$ but were nevertheless included in the overall summations to derive the mean net exchange per tide $(\bar{x})$ for each component, Units are in $\mathrm{kg} C, \mathrm{~N}$ or $\mathrm{P}$ as appropriate

\begin{tabular}{|c|c|c|c|c|c|c|}
\hline $\begin{array}{l}\text { Month of } \\
\text { sampling }\end{array}$ & $\mathrm{DOC}$ & DON & DOP & $\mathrm{NH}_{4}$ & $\left(\mathrm{NO}_{3}+\mathrm{NO}_{2}\right)$ & $\mathrm{PO}_{4}$ \\
\hline Dec ' 82 & nd & 40.0 & $(19.1)$ & $(6.1)$ & $(2.4)$ & 10.2 \\
\hline Jan ' 83 & nd & 14.0 & 3.3 & 10.4 & 9.1 & 8.1 \\
\hline Mar & nd & $(33.5)$ & 10.7 & 16.0 & -2.2 & -3.1 \\
\hline May & nd & $(12.6)$ & (10.9) & -1.7 & -4.2 & 0.8 \\
\hline Jul & -137 & $(-2.8)$ & nd & $(-0.8)$ & -0.2 & 1.1 \\
\hline Aug & -146 & -27.4 & 3.1 & $(-0.1)$ & -0.5 & -0.4 \\
\hline Sep & 408 & 34.5 & $(-2.3)$ & 2.4 & $(0.7)$ & -1.3 \\
\hline Nov & 3 & -29.5 & -2.5 & $(-0.9)$ & $(-0.1)$ & -0.3 \\
\hline Dec & 24 & $(-0.1)$ & 0.1 & nd & 0.2 & 1.7 \\
\hline $\operatorname{Jan} ' 84$ & 35 & $(13.1)$ & -1.2 & $(1.2)$ & -1.4 & 0.2 \\
\hline Feb & 206 & 15.8 & $(-0.8)$ & $(-3.7)$ & -3.5 & -2.5 \\
\hline Mar & 188 & 28.3 & -0.4 & -6.2 & -2.1 & -0.4 \\
\hline Apr & 69 & $(-2.3)$ & $(2.6)$ & -2.5 & -3.1 & $(-0.8)$ \\
\hline May & -110 & $(1.8)$ & $(0.5)$ & $(0.7)$ & 0.7 & $(0.7)$ \\
\hline $\operatorname{Jul}(1)^{\mathrm{a}}$ & 90 & 6.3 & (1.1) & -5.2 & 0.7 & $(-0.4)$ \\
\hline Jul (2) & (6) & $(8.2)$ & $(-3.2)$ & $(1.2)$ & $(0.3)$ & $(1.6)$ \\
\hline $\bar{x}$ & 53 & 9.1 & 2.7 & 1.1 & -0.2 & 1.0 \\
\hline
\end{tabular}

gave mean temperature (T) and mean solar radiation (I) as significant predictor variables:

$$
\begin{aligned}
{\left[\mathrm{NO}_{2}+\mathrm{NO}_{3}\right]=} & -0.73+0.052 \mathrm{~T}-0.000032 \mathrm{I} \\
& \left(\mathrm{R}^{2}=0.793\right)
\end{aligned}
$$

with $F_{2,12}$ (regression) $=23.0$. The 'jacknife' test in this case gave a reasonably small decrease in $R^{2}$ from 0.793 to 0.679 indicating that the original good fit was unlikely to be simply an artifact arising from the limited data set used to develop the regression

The influence of solar irradiation on nitrate concentrations was also apparent from the July 1984 diurnal comparisons where the mean concentration at night $\left(0.11 \mu \mathrm{mol} 1^{-1}\right)$ was significantly greater than the mean daytime concentration (0.05). Phosphate concentrations were also significantly higher at night, although the differences were less marked (0.22 vs 0.19 umol $1^{-1}$, while ammonium levels were significantly lower at night $\left(0.22\right.$ vs $\left.0.43 \mu \mathrm{mol} \mathrm{l^{-1 }}\right)$. Neither DOC, DON or DOP showed significant day-night differences.

Many of the dissolved components showed significant, and in some cases quite high, intercorrelations (Table 1), possibly reflecting similar rates of production and uptake by bacteria and phytoplankton. Interestingly, DOC did not correlate with either DON or DOP, and the atomic $C: N$ and $C: P$ ratios for the organic materials were consistently high, in the range 18 to $35: 1$ and 250 to $700: 1$ respectively.

Variations in the concentrations of most of the dis- solved components were typically small over average tidal cycles (Fig. 3). DOC and nitrate concentrations usually varied in a systematic manner with change in tide height and were generally significantly and negatively correlated with the volume of water contained in the basin $(|r|$ typically $>0.8)$. The concentration of the other dissolved components often showed significant but non-systematic variations with tidal volume. Correlations between phosphate concentrations and tidal volume were highly variable ranging from significantly

Table 3. Estimated net annual exchanges of the dissolved components in Coral Creek and the proportion of net forest primary production requirements (Boto \& Bunt 1981a, 1982)

represented by each (negative sign denotes net export)

\begin{tabular}{|lcc|}
\hline Component & $\begin{array}{c}\text { Net annual } \\
\text { exchange } \\
(\mathrm{g} \mathrm{C}, \mathrm{N} \text { or } \\
\left.\mathrm{P} \mathrm{m}^{-2} \mathrm{yr}^{-1}\right)\end{array}$ & $\begin{array}{c}\text { Proportion of } \\
\text { primary } \\
\text { production } \\
\text { requirements } \\
(\%)\end{array}$ \\
\hline $\mathrm{DOC}$ & 7.3 & 0.8 \\
$\mathrm{DON}$ & 1.3 & 4.7 \\
$\mathrm{DOP}$ & 0.37 & 17.9 \\
$\mathrm{NH}_{4}$ & 0.15 & 0.6 \\
$\mathrm{NO}_{3}+\mathrm{NO}_{2}$ & -0.03 & -0.1 \\
$\mathrm{PO}_{4}$ & 0.13 & 6.3 \\
Total dissolved $\mathrm{N}$ & 1.45 & 5.4 \\
Total dissolved $\mathrm{P}$ & 0.50 & 24.2 \\
\hline
\end{tabular}


negative to positive and in an apparently stochastic manner from one tidal cycle to the next. Ammonium distribution was extremely patchy, with replicate samples often ranging from 0 to $1.0 \mu \mathrm{mol} \mathrm{l}^{-1}$. This typically high within-sample variance usually resulted in the within-cycle variation being non-significant despite the apparently wide range of mean ammonium concentrations during a given tidal cycle

A summary of net material exchange estimates for each of the dissolved components (Table 2) during each tidal cycle sampled, showed that only those for DOC, nitrate + nitrite, and phosphate were consistently statistically significant. It is, however, highly likely that these estimates are subject to greater uncertainty than implied by the statistical analyses used here as the calculations have assumed no error in the water flux estimates derived from the mathematical model. In any event, there was no evidence of consistent seasonal variation in the exchange estimates for any of the dissolved components. Annual total exchange estimates (Table 3 ) were compared with the estimates of forest primary production $\mathrm{C}, \mathrm{N}$ and $\mathrm{P}$ requirements (Boto \& Bunt 1982) for the Coral Creek mangrove forests. With the possible exception of $\mathrm{P}$, where a net annual import of total dissolved $\mathrm{P}$ was estimated to account for ca $24 \%$ of forest primary production requirements, the net annual flux of dissolved components was negligible (C:0.8\% and total dissolved N : $5.3 \%$ - both imports).

\section{DISCUSSION}

The Coral Creek study site presented the opportunity to investigate the concentrations and fluxes of dissolved components in a tropical mangrove forest which is influenced almost entirely by tidal action and with virtually no effects from terrestrial runoff or groundwater input. In this regard, the Coral Creek/Missionary Bay mangroves are typical of many of the very large mangrove forests in northern Australia. Interestingly, the results obtained for the Coral Creek mangroves differ considerably from those obtained from most previous studies of salt marshes and mangroves and it is reasonable to attribute these differences to the lack of influence from terrestrial sources in the Coral Creek system.

The generally low concentration of all of the dissolved materials in Cora] Creek was in marked contrast to the results reported for temperate salt marshes and subtropical or tropical mangroves (Valiela et al. 1978, Chrzanowski et al. 1983, Imberger et al. 1983, Nixon et al. 1984, Twilley 1985). For example, ammonium concentrations in the order of 5 to $2011 \mathrm{~mol} 1^{-1}$ have been reported for salt marsh. waters whereas the highest concentration (for an individual sample) found in Coral Creek was 1.6 mol $^{-1}$ with most samples less than 0.5 $\mu \mathrm{mol} \mathrm{l}^{-1}$. Nitrate (and nitrite) concentrations were also generally very low, rarely exceeding $0.3 \mu \mathrm{mol} \mathrm{l}^{-1}$, compared with concentrations at least one order of magnitude greater commonly reported in salt marsh waters. DOC levels were also low in Coral Creek, rarely exceeding $2 \mathrm{mg} \mathrm{Cl}^{-1}$, compared with concentrations of up to $13 \mathrm{mg} \mathrm{Cl}^{-1}$ commonly measured in salt marsh waters. The concentrations of DOC in the Florida basin forests studied by Twilley (1985) were also generally much higher (in the range 5 to $20 \mathrm{mg} \mathrm{Cl}^{-1}$ ) than found in the present study. These profound differences in dissolved material levels as compared with Coral Creek may result from differences in climatic regime (temperate vs tropical), the degree of freshwater' terrestrial influence, or the local hydrography or topography - as is almost certainly the case of the basin mangroves. It is not possible to determine the contribution from sources external to the marshes or mangroves for the previous studies although it is interesting that Nixon et al. (1984), from their study of Malaysian estuaries, also reported much higher concentrations of dissolved organic and inorganic nutrients than were found in the present study.

In the Malaysian study, the high nutrient concentrations almost certainly resulted from freshwater input to the estuaries as there was little difference in the concentrations of total dissolved nutrients between the estuary containing mangrove forests and that from which mangroves had been previously removed for agricultural purposes, although some differences in the speciation of the dissolved materials were apparent. For example, ammonium was the major dissolved inorganic $N$ species in the mangrove-influenced estuary whereas nitrate predominated in the other.

Although the mean concentrations of most of the dissolved species in Coral Creek showed significant variations with time throughout the study period, there was little evidence of any consistent seasonal effect with timing and duration of peak periods being quite different from the first year to the next for most of the species. Accordingly, the concentrations of the dissolved entities showed weak, and mainly non-significant correlations with simple climatic parameters. Although nitrate + nitrite concentrations appeared to be well predicted using temperature and light the utility of such a model is questionable as nitrate + nitrite constituted only a small proportion (ca 2 to $3 \%$ ) of the total dissolved nitrogen in these waters.

The significantly lower concentrations of nitrate + nitrite and phosphate during daylight hours, as compared with nighttime levels, suggests that uptake by phytoplankton, benthic algae or the mangroves can give rise to small but significant short-term variations 
in these components. Ammonium concentrations, on the other hand, were significantly greater during daytime suggesting that other unexplained factors play a greater role in determining the considerable short term variability in this component. The lack of any significant day-night differences for all of the other dissolved species implies that uptake or exudates by phytoplankton, benthic algae or the mangrove forest have little effect on these. In direct contrast, the southern Indian mangrove system studied by Balasubramanian \& Venugopalan (1984) showed strong seasonal peaks in

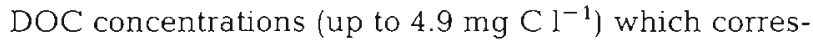
ponded with very high phytoplankton populations in the July-September period. However, the chlorophyll a levels reported for their system, of up to $20 \mu \mathrm{g} \mathrm{l} \mathrm{l}^{-1}$, are an order of magnitude greater than has been recorded for the Coral Creek waters (Boto \& Bunt 1981a).

Mangrove waters, being normally very turbid, are generally considered to contain low populations of phytoplankton (Gong 1984) and hence the Indian system does not appear to be typical of most mangroves.

The lack of correlation between DOC and either DON or DOP for the Coral Creek waters suggests that the majority of the carbon is in the form of compounds containing low proportions of $\mathrm{N}$ or $\mathrm{P}$, for example humic compounds or mangrove-derived polyphenolics which previous studies have indicated as major components of these waters (Boto \& Bunt 1981b). In addition, Stanley et al. (1987) found that dissolved free amino acids account for only ca 1 and $10 \%$ respectively of the DOC and DON in these waters. The high $C: N$ or $C: P$ ratios for the dissolved organics, substantially higher than the Redfield ratios (6:1 and 106:1, respectively; Redfield et al. 1963) also suggest that the DOC is mainly of a refractory nature and in an advanced state of diagenesis, for example fulvic and humic acids (Sandstrom 1982).

Annual net transport estimates strongly suggest that the system is in a finely balanced state as far as inputs and outputs of dissolved materials are concerned. Despite the problems inherent in the 'Eulerian' approach used in this study to calculate the material fluxes (Imberger et al. 1983), the overall trend emerging from the present results is quite clear. For all components except phosphate, there was no evidence to suggest any consistency in direction or magnitude of net flux estimates and, when summed over a full year, net transport in either direction was negligible. Total dissolved phosphorus, however, showed a significant net annual import amounting to ca $24 \%$ of net forest primary production requirements. This result is consistent with results from previous studies of this system which have provided strong evidence that the forests are phosphate-limited especially in the mid to upper intertidal zones (Boto \& Wellington 1983). That same study, however, also showed strong evidence that nitrogen limitation was ubiquitous in these forests whereas the present study points to only a very small, and not statistically significant, net import of dissolved nitrogen into the system (ca $5 \%$ of forest net primary production requirements).

This study, in conjunction with previous estimates of particulate material transport from the same system, suggests that virtually all net transport (export) is in the form of particulate matter, predominantly mangrove plant litter such as leaves, flower parts and propagules (Boto \& Bunt 1981a, 1982). Interestingly, summing all estimates for particulate and dissolved material transport, it is readily apparent that the forest tends to conserve nitrogen and phosphorus. Total net annual transport of $\mathrm{C}, \mathrm{N}$ and $\mathrm{P}$ - expressed as a percentage of forest net primary production requirements - is estimated to be $(+=$ import, $-=$ export $): \mathrm{C}=-35 \%, \mathrm{~N}=$ $-8 \%$ and $\mathrm{P}=+12 \%$. Despite the uncertainty in these estimates, especially for $\mathrm{N}$ and $\mathrm{P}$, the forests appear to be in a finely balanced state with respect to the primary macronutrients and it is likely that these are efficiently recycled within the forest.

The present study provides an interesting comparison with most previous studies of salt marshes where net transport, usually export, of dissolved materials has been quite considerable. In some cases (e.g. Valiela et al. 1978) the significant net export of dissolved inorganic nutrients, particularly nitrate, has been attributed to the influence of terrestrial runoff through riverine or groundwater inflow. Chrzanowski et al. (1983), in their study of DOC transport in the North Inlet System, South Carolina, estimated a net annual export of DOC at a rate close to, or exceeding, the net aerial production of the marsh Spartina vegetation. They suggest that this very high rate of export may be attributed to a number of factors including ground water input.

In many other instances the potential influence of terrestrial input appears to be less recognized. Our ongoing studies of tropical mangrove estuarine systems will therefore provide an interesting measure of the importance of such external influences and perhaps help to determine the potential for estuarine mangroves to 'buffer' inputs of nutrients and other entities emanating from terrestrial sources, and which would otherwise directly affect near-shore waters (cf. Kennedy 1984).

Acknowledgements. The authors gratefully acknowledge the helpful advice and assistance from E. Wolanski, particularly in the provision and use of the Coral Creek hydrodynamic model V. Ryle, B. Harkin and other staff of the AIMS Laboratory Services unit assisted greatly with the nutrient analyses. D. Alongi, B. Clough, A. Robertson and T J. Smith provided useful criticism and advice on earlier versions of this manuscript. The assistance of S. Lager and J. Creek in the field is gratefully acknowledged. 


\section{LITERATURE CITED}

Balasubramanian, T., Venugopalan, V K. (1984). Dissolved organic matter in Pitchawaram mangrove environment Tamil Nadu, South India. In: Soepadmo, E., Rao, A. N., Macintosh. D. J. (eds.) Proceedings of the Asian Symposium on Mangrove Environment: research and Management. University of Malaya, Kuala Lumpur, p. 496-513

Boto, K. G. (1982). Nutrient and organic fluxes in mangroves. In: Clough, B. F. (ed.) Mangrove Ecosystems in Australia: Structure, Function and Management. Australian Institute of Marine Science. Australian University Press, Canberra, p. 239-257

Boto, K. G., Bunt, J. S. (1981a). Tidal export of particulate organic matter from a northern Australian mangrove system. Estuar. coast. Shelf Sci. 13: 247-255

Boto, K. G., Bunt, J. S. (1981b). Dissolved oxygen and $\mathrm{pH}$ relationships in northern Australian Mangrove waterways. Limnol. Oceanogr. 26: 1176-1178

Boto, K. G., Bunt, J. S. (1982). Carbon export from mangroves. In: Galbally, I. E., Freney, J. R. (eds.) The cycling of Carbon, Nitrogen, Sulfur and Phosphorus in Terrestrial and Aquatic Ecosystems. Australian Academy of Science, Canberra, p. 105-110

Boto, K. G., Wellington, J. T (1983). Phosphorus and nitrogen nutritional status of a northern Australian mangrove forest. Mar. Ecol. Prog. Ser. 11: 63-69

Chalmers, A. G., Wiegert, R. G., Wolf, P. L. (1985). Carbon balance in a saltmarsh: interactions of diffusive export, tidal deposition and rainfall-caused erosion. Estuar. coast. Shelf Sci. 21: 757-771

Chrzanowski, T H., Stevenson, L. H., Spurrier, J. D. (1983). Transport of dissolved organic carbon through a major creek of the North Inlet ecosystem. Mar. Ecol. Prog. Ser. 13: $167-174$

Geisser, S. (1975). The predictive sample reuse method with applications. J. Am statist. Ass. 70: 320-328

Gong, W. K. (1984). Mangrove primary productivity. In: Ong, J. E., Gong. W. K. (eds.) Productivity of the mangrove ecosystem: management implications. University Sains Malaysia, Penang, p. 10-19

Haines, E. B. (1979). Interactions between Georgia salt marshes and coastal waters: a changing paradigm. In: Livingston, R. J. (ed.) Ecological processes in coastal and marine systems. Proceedings of the Symposium at Florida State University, April 1978. Plenum Press, New York, p. $35-46$

Imberger, J., Berman, T., Christian, R. R., Sherr, E. B., Whitney, D. E., Pomeroy, L. R., Wiegert, R. G., Wiebe, W. J. (1983). The influence of water motion on the distribution and transport of materials in a salt marsh estuary. Limnol. Oceanogr. 28: 201-214

Kennedy, V S. (ed.) (1984). The estuary as a filter. Estuanne Research Federation. Academic Press, New York

Mueller, H., Bandaranayke, W. (1983). An automated method for the determination of dissolved organic carbon in seawater using continuous thin-film UV oxidation. Mar Chem. 12: 59-68

Nixon, S. W., Furnas, B. N., Lee, V., Marshall, N., Ong, J. E., Wong, C. H., Gong, W K., Sasekumar, A. (1984). The role of mangroves in the carbon and nutrient dynamics of Malaysia estuaries. In: Soepadmo, E., Rao, A. N., Macintosh, D. J. (eds.) Proceedings of the Asian Symposium on
Mangrove Environment: research and management. University of Malaya, Kuala Lumpur, p. 535-544

Odum, W E., Fisher, J. S., Pickral, J. C. (1979) Factors controlling the flux of particulate organic carbon from estuarine wetlands. In: Livingstone, R. J. (ed.) Ecological processes in coastal and marine Systems. Plenum Press, New York, p. 69-80

Odum, W E., McIvor, C. C., Smith, T. J., III. (1982). The ecology of the mangroves of south Florida: a community profile, U.S. Fish and Wildlife Service, Office of Biological Services, Washington, D.C. FWS/OBS-81/24

Redfield, A. C., Ketchum, B. H., Richards, F. A. (1963). The influence of organisms on the composition of seawater. In: Hill M. N. (ed.) The Sea, Vol. 2. Interscience, New York, p. 26-77

Robertson, A. I. (1986). Leaf-burying crabs: their influence on energy flow and export from mixed mangrove forests (Rhizophora spp.) in northeastern Australia. J. exp. mar. Biol. Ecol. 102: 237-248

Ryle, V D., Mueller, H. R., Gentien, P. (1981). Automated analysis of nutrients in Tropical Sea Waters. Australian Institute of Marine Science Technical Bulletin: Oceanography Series No. 3. AiMiS-OS-81-2, Townsville

Sandstrom, M. W. (1982). Diagenesis of organic phosphorus in marine sediments: implications for the global carbon and phosphorus cycles. In: Galbally, I. E., Freney, J. R. (eds.) (1982). The cycling of carbon, nitrogen, sulfur and phosphorus in terrestrial and aquatic ecosystems. Australian Academy of Science, Canberra, p. 133-141

Settlemeyer, J. L., Gardner, L. R. (19777. Suspended sediment flux through a salt marsh drainage basin. Estuar. coast. mar. Sci. 5: 653-663

Sokal, R. R., Rohlf, F. J. (1981). Biometry, The principles and practice of statistics in biological research. W. H. Freeman and Co., San Francisco

Stanley, S. O., Boto, K. G., Alongi, D. M., Gillan, F. T. (1987). Composition and bacterial utilization of free amino acids in tropical mangrove sediments. Mar. Chem. 22: 13-30

Strickland, J. D. H., Parsons, T R. (1972). A practical handbook of seawater analysis. Bull. Fish. Res. Bd Can. 167

Teal, J. M. (1962). Energy flow in a salt marsh ecosystem of Georgia. Ecology 43: 614-624

Twilley, R. R. (1985). The exchange of organic carbon in basin mangrove forests in a southwest Florida estuary. Estuar. coast. Shelf Sci. 20: $543-557$

Valiela, I., Teal, J., Volkmann, S., Shafer, D., Carpenter, E. J. (1978). Nutrient and particulate fluxes in a salt marsh ecosystem: tidal exchanges and inputs by precipitation and groundwater. Limnol. Oceanogr 23: 798-812

Wolanski, E., Jones, M., Bunt, J. S. (1980). Hydrodynamics of a tidal creek - mangrove swamp system. Aust. J. mar. Freshwat. Res. 31 431-450

Wolanski, E., Gardiner, R. (1981). Flushing of salt from mangrove swamps. Aust. J. mar. Freshwat. Res. 32: 681-683

Woodroffe. C. D. (1985a). Variability in detrital production and tidal flushing in mangrove swamps. In: Bradsley, K. N., Davie, J. D. S., Woodroffe, C. D. (eds.) Coasts and tidal wetlands of the Australian monsoon region. Australian National University North Australia Research Unit Mangrove Monograph No. 1, Darwin, p. 201-212

Woodroffe, C. D. (1985b). Studies of a mangrove basin, Tuff Crater, New Zealand. III The flux of organic and inorganic particulate matter. Estuar. coast. Shelf Sci. 20. 447-462 